\title{
The UK's Digital Road to Recovery
}

BY JONATHAN LIEBENAU, ROBERT ATKINSON, PATRIK KÄRRBERG, DANIEL CASTRO AND STEPHEN EZELL I APRIL 2009

Spurring investments in ICT infrastructure not only can provide an important short-term boost to the UK economy; it also can lay the groundwork for long-term economic growth, international competitiveness, and significant improvement in quality of life.

\section{LSE Enterprise}

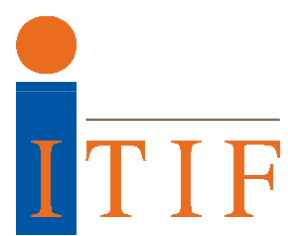

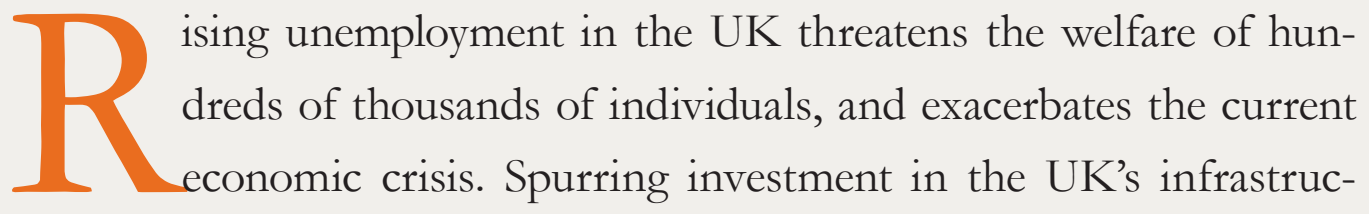

ture is an effective immediate strategy to compensate for the downturn. However, while investments to improve the country's traditional physical infrastructure (roads, bridges, sewer systems, etc.) are necessary and important, investments in certain parts of the UK's information and communication technology (ICT) resources, or digital infrastructures, will have a greater positive impact on jobs, while at the same time laying the groundwork for sustained productivity and innovation. The United Kingdom has made considerable efforts to be one of the leading nations in the production and utilisation of ICT; the current recession offers an opportunity to further, rather than undermine, those efforts. This ambition is consistent with the Chancellor's 2009 Budget as well as recent studies by the National Endowment for Science, Technology and the Arts (NESTA), the Confederation of British Industry (CBI), HM Treasury and the Department for Business, Enterprise \& Regulatory Reform (DBERR). ${ }^{1}$

In this report, researchers from the London School of Economics and Political Science (LSE) and the Information Technology and Innovation Foundation (ITIF) assess the employment impact of investments in three ICT infrastructures: broadband networks, intelligent transportation systems, and the smart power grid, that (1) contribute to signifi- cant immediate direct and indirect job growth in the UK economy; (2) create a "network effect" throughout the economy that creates additional jobs; and (3) provide a foundation for longer term benefits, including government cost savings, economy-wide productivity, and improved quality of life for all. Our major findings are as follows: 


\section{Investments in the UK's digital infrastructure} will spur significant job creation in the short run.

We estimate that spurring an additional investment of $£ 15$ billion in the UK's ICT infrastructure would create approximately 700,000 UK jobs (see Table 1). We also estimate that over half of these jobs would be in small businesses (defined as firms having fewer than 250 employees). Please note that we use a $£ 5$ billion investment in these examples for illustrative purposes. We are not advocating a specific level of investment in this report.

- Broadband networks: An additional $£ 5$ billion investment in broadband networks would create or retain an estimated $280,500 \mathrm{UK}$ jobs for a year.

- Intelligent transportation systems (ITS): An additional $£ 5$ billion investment in intelligent transportation systems would create or retain an estimated 188,500 UK jobs for a year.

- Smart power grid: An additional $£ 5$ billion investment in the smart grid would create or retain an estimated 231,000 UK jobs for a year.

Investments in ICT infrastructure should not be minimised out of concern that the projects will take too long to begin to have an immediate impact on the economy. If the initiatives are designed properly, they can quickly spur a large number of investments-from deploying more and faster broadband networks to implementing intelligent transportation systems to rolling out advanced energy metering technologies (smart meters) — that are currently ripe for development.
2. Investments in these digital infrastructures will create a network effect (or network externality) that will offer superior job creation benefits because of the "network multiplier."

Infrastructure investments-of both the digital and physical variety-will create direct jobs, indirect jobs, and induced jobs. Consider an investment in broadband networks or highway infrastructure. Direct jobs are those created specifically by new spending (e.g., the technicians or road workers hired to lay broadband "pipes" or tarmac). Indirect jobs are those created to supply the materials and other inputs to production (e.g., fibre optic cable or concrete). Induced jobs are those created by newly employed (or retained) workers spending their wages, thus creating jobs in establishments such as restaurants and retail stores.

A multiplier is a number that expresses the extent to which a change in a given economic activity generates additional effects through interdependencies associated with some linkage system. Thus, when calculating employment growth generated by a given level of investment, employment multipliers are used to estimate the number of indirect and induced jobs created.

However, investing in certain types of ICT infrastructure offers superior job creation benefits because it creates a "network effect." "This network effect leads to an additional employment growth multiplier, herein referred to as the "network multiplier," which arises from the new consumer and business behaviours, functionalities, and downstream industries enabled by the ICT infrastructure. The network effect employment multiplier refers to the new jobs that will be created through

TABLE 1: ESTIMATES OF UK JOBS CREATED OR RETAINED BY INVESTMENTS IN NETWORK INFRASTRUCTURES FOR 1 YEAR

\begin{tabular}{l|c|c|c} 
ICT Investment & Investment & Total Jobs & Small Business Jobs \\
\hline Broadband networks & $£, 5$ billion & 280,500 & 94,000 \\
ITS & $£ 5$ billion & 188,500 & 120,000 \\
Smart power grid & $£ 5$ billion & 231,000 & 146,000 \\
Total & $£$ 15 billion & $\mathbf{7 0 0 , 0 0 0}$ & $\mathbf{3 6 0 , 0 0 0}$
\end{tabular}


the new applications and services-some manifested in entirely new industries - that digital infrastructure makes possible. This possibility arises because digital infrastructures act as platforms that serve as the foundation for a multitude of innovative technologies and services. ${ }^{3}$

ICT infrastructure projects create more bigh-skilled, high-paying jobs; ICT jobs on average pay over 80 percent more than average jobs.

Investments in networks that are at an early stage of development-including broadband, ITS, and the smart grid-will create even more additional jobs as a result of the network effect. Building out these networks leads to new jobs generated by upstream investment in industries that create new and innovative applications and services to take advantage of the more robust ICT network. For example, building the smart power grid will spur a host of innovative new products and services from hybrid plug-in electric vehicles to smart appliances to more investment in renewable energy. In contrast, public expenditures (either through grants or tax incentives) to support expanding a mature network using relatively mature technology, on the other hand, will not yield comparable network effects. Building or repairing highways-while certainly a necessary investment to maintain the nation's physical infrastructure-will not likely spur innovations in the auto industry or purchases of better tyres for cars. Thus these more traditional investments are less likely to create additional jobs through network effects. ${ }^{4}$ ICT infrastructure projects also create more high-skilled, high-paying jobs; ICT jobs on average pay over 80 percent more than average jobs. ${ }^{5}$

No widely applied econometric technique is currently used to capture the effects of digital infrastructure investments in broadband networks, ITS, and the smart grid. This situation may put ICT infrastructure projects at a disadvantage in comparison with more traditional infrastructure projects that economists and policymakers are more familiar with. For that reason, as described below, LSE and ITIF have developed estimates of the network effect of ICT infrastructure investments.

\section{Investments in the UK's digital infrastructure will lead to higher productivity, increased com- petitiveness, and improved quality of life in the moderate to long term.}

ICT infrastructure projects, in addition to providing an opportunity for creating jobs today, have the potential to spur long-term economic growth. ${ }^{6}$ LSE's Centre for Economic Performance (CEP) ${ }^{7}$ and ITIF have shown in previous reports and studies that ICT is central to economic growth. ICT has played an important role in productivity and economic growth in most developed nations, including the United Kingdom. For example, from 1995 to 2000, ICT helped spur annual productivity growth in the UK by approximately 0.9 percent per year. ${ }^{8}$ From 2000 to 2005, ICT continued to perform, contributing around one percentage point per year to growth in labour productivity in many nations. ${ }^{9}$ In addition, a recent UK study found that ICT investment by firms in the UK had significant impacts on productivity and even larger ones when coupled with organizational change that ICT makes possible. ${ }^{10} \mathrm{~A}$ further CEP study convincingly demonstrated the ICT component of this productivity advantage by showing that U.S.-owned subsidiaries in the UK (versus their domestic and other foreign-owned counterparts) performed better for reasons associated with higher returns from utilising ICT. ${ }^{11}$

Spurring investments in digital infrastructures will also create a market for the goods and technical services of domestic firms. Investing in these infrastructures now will help ensure that domestic firms have the knowledge, skills, and abilities needed to become chief exporters of this technology (e.g., ITS and smart grid components and services) as other countries expand their own digital infrastructure initiatives. Thus an investment in digital infrastructures not only will spur short-term job growth but will enhance long-term competitiveness and lead to the expansion of higher value-added UK jobs.

Finally, the network effect of these ICT infrastructure projects, beyond leading to additional job creation, higher productivity, and increased competitiveness, is also indicative of the positive personal and societal benefits generated by such investments. Spurring the investment of $£, 5$ billion in ITS, for example, not only will create 188,500 UK jobs but will also improve 
road safety and reduce traffic congestion. The network effects will go even further as advances in ITS will support applications like real-time traveller information systems, more efficient freight logistics, and more traveller-friendly transit systems. Likewise, increased broadband infrastructure will spur improvements in educational outcomes, enable more telecommuting, and have a wide range of other societal benefits. ${ }^{12}$ And investments in the smart power grid will produce significant energy savings, contributing to a less carbonintensive economy.

\section{THE CASE FOR ACCELERATED ICT INFRASTRUCTURE INVESTMENTS}

ICT investments have been a part of HM Treasury's investment plans for many years now. Major national investments have been made in extending computing to Britain's schools, to local and national government services, and most notably to transform the National Health Service. Britain's standing as a leader in e-government is highly regarded throughout the European Union and with perhaps a few exceptions has seen great benefits from judicious use of ICT.

The sense of urgency that the nation is addressing is new. In the last budget, the scene looked vastly different; the UK economy enjoyed record levels of employment and was portrayed as having achieved over the past decade "much improved resilience-the ability to cope with economic shocks quickly and with low economic costs - which has resulted in an unprecedented period of macroeconomic stability." ${ }^{13}$ Nevertheless, the need to invest in greater productivity growth was apparent and, based to some degree on HM Treasury's 2007 Comprehensive Spending Review, investments in improved infrastructure and the science and innovation system were specified. ${ }^{14}$ In the year since the 2008 budget, however, unemployment has exceeded 2 million and appears likely to continue to rise, at least in the near term, adding a compelling reason for accelerating digital infrastructure investments. ICT investment has frequently been regarded as a priority, despite great uncertainty, by HM Treasury. ${ }^{15}$ While the immediate needs of the Winter of 2008-2009 seemed to be in the area of financial intervention to support lending, if a multibillion pound investment programme is necessary to boost the UK economy, the question is not so much, "should money be spent?" but rather, "where should the money be invested?" Ignoring ICT infrastructure investments will do nothing to save British taxpayers' money; instead, it will simply shift the proportion of the economic investment that goes to other areas, most of which, including personal consumption, do not offer many added benefits such as productivity or innovation.

The areas we use to demonstrate the case for accelerated ICT infrastructure investments are all areas where government's involvement is essential both because of the scale and national reach and because of the coordination necessary to sustain and extend benefits. The private sector will tend to underinvest in these networks because it is unable to capture all of the benefits (externalities) of its investments and because of other well-documented market failures, including "chicken or egg" challenges where the success of network investments is premised upon investments by other players also taking place. In broadband, for example, significant network externalities exist that consumers of broadband by definition do not receive. ${ }^{16}$ Moreover, building out some parts of the broadband network, particularly to high-cost areas, is not economical absent some incentives. The same is true with the smart grid, where savings from energy efficiency and reduced pollution benefit everyone, not just certain customers. The UK should take a page from other nations like Japan, South Korea, and Sweden, which have successfully used incentives, including tax incentives, to spur the private sector to invest more in digital infrastructures. $^{17}$

To achieve the vision put forward in this report, the Government should use a mix of policy tools including tax credits, grants, other Government investment, and regulatory changes to spur private investment in these infrastructures. The goal of these activities is to induce new investment in these areas and encourage companies to expedite existing investment plans. For example, the Government can use tax incentives that support qualified investments in 2009 and 2010 to encourage broadband providers and utilities to expand investments in broadband networks and the smart grid. Government-sponsored grant programs can also fund new initiatives for broadband, smart grid and intelli- 
gent transportation systems and expand existing public programmes in these areas. To spur investment in the smart grid, to take one example, these grants may include pilot programmes for utilities to install smart meters or other scalable smart grid infrastructure. The Government can also use subsidies to spur the use of these technologies, for example, through direct subsidies to households to make next-generation broadband more affordable or by subsidising the acceleration of deploying smart meters to British homes.

Government can also leverage various budget-neutral policy tools to stimulate investment in ICT infrastructure in the near and long term. For example, as the National Endowment for Science, Technology and the Arts (NESTA) has described, to promote investment in high-speed broadband Internet Ofcom could swap highly sought-after licenses for radio spectrum in exchange for broadband infrastructure delivery. To increase investment in ITS projects, Government can increase the share of transport funding allocated to ITS than traditional infrastructure projects. ${ }^{18}$ Government can also use policy to promote investment in smart grid technology by, for example, enacting regulatory changes to mandate smart metering, create cost recovery mechanisms for utilities and ensure clear market incentives exist for smart grid investments. Finally, Government departments can accelerate existing projects to 2009 and 2010, such as investment planned by the Department for Transportation on ITS. The longterm impact on the budget would be the same from such acceleration but the short term economic impacts would be larger and the long-term benefits would be gained sooner.

\section{METHOD OF THE STUDY}

To measure the impact of additional investment in the areas of broadband networks, ITS, and the smart power grid on direct jobs, indirect jobs, and induced jobs, LSE and ITIF used standard economics methodology. We determined the specific impact of such investments on direct, indirect, and induced employment by taking estimates of the economic employment and output multipliers from the Office of National Statistics and especially the more recent ones produced for Scotland. ${ }^{19}$ Although these figures are not easily comparable with U.S. and other OECD data (but are likely to be so in the coming years), we were able to arrive at useable estimates that portray the labour market effects of additional investment. ${ }^{20}$ Sufficient UK data was not always available for our models, and so, at times, we have substituted U.S.-based statistics and support where we believe it contributes to a more accurate projection.

The private sector will tend to underinvest in these networks because it is unable to capture all of the benefits (externalities) of its investments and because of other well-documented market failures, including "chicken or egg" challenges where the success of network investments is premised upon investments by other players also taking place.

In addition, LSE and ITIF estimated the number of jobs that would be created in small businesses (defined here as firms with fewer than 250 employees) by these ICT infrastructure investments. For direct jobs, we based our estimates on the industry ratio of the workforce in small businesses to total industry workforce. To calculate the share of indirect jobs attributable to small businesses, we analysed the largest intermediate input industries to the industries in question and assessed the percentage of the workforce in those industries found in small to medium-sized businesses. Finally, we estimated the number of induced jobs and jobs created from the network effect to be in proportion to the overall share of small business jobs in the UK economy-49.2 percent. $^{21}$

\section{BROADBAND NETWORKS}

We estimate that spurring $f 5$ billion of investment in broadband networks would support approximately 280,500 new or retained jobs for a year (see Table 2).

High-speed broadband Internet access is increasingly viewed as an essential infrastructure for our information economy. ${ }^{22} \mathrm{~A}$ recent multinational study found that an extra ten percentage points of broadband penetration by 2006 accounted for a full 1.21 percentage 
TABLE 2: UK JOBS CREATED OR RETAINED FOR 1 YEAR BY A £5 BILLION BROADBAND INVESTMENT

\begin{tabular}{l|c|c} 
Job Type & Total Jobs & Small Business Jobs \\
\hline Direct & 76,500 & 22,500 \\
Indirect \& Induced & 134,500 & 37,000 \\
Network effect & 69,500 & 34,500 \\
Total Jobs & $\mathbf{2 8 0 , 5 0 0}$ & $\mathbf{9 4 , 0 0 0}$
\end{tabular}

point increase in per capita gross domestic product (GDP) growth in developed economies. ${ }^{23}$ Broadbandenabled Internet business solutions are expected to add a total of 0.43 percentage points to U.S. productivity growth through 2011 and could be expected to contribute similarly to the UK economy. ${ }^{24}$ Broadband is therefore an essential contributor to long-term economic, productivity, and wage growth.

The UK has a well developed broadband markets. In 2008, 56 percent of all UK households had a broadband connection, up from 51 percent in 2007. However, UK broadband networks are relatively slow, especially compared to world leaders. Improving broadband speeds is a central challenge for the UK. In the UK the average speed of broadband Internet access is 3 to $4 \mathrm{Mbps}$ - but this varies widely depending on location. When average broadband speed is considered along with subscription rates, the UK ranks 13th, behind several fellow European countries including Sweden, Denmark, the Netherlands, France, Belgium, and Germany, as well behind the world leaders of Japan and South Korea. ${ }^{25}$ For example, average broadband download speeds in France and Japan are over $40 \mathrm{Mbps}$ and $100 \mathrm{Mbps}$, respectively. ${ }^{26}$ Telecoms firms will boost speeds by replacing ageing copper cables with fibre optics to carry data.

Generous government subsidies, including tax incentives, to telecoms firms in Japan and Korea helped them become the world leaders in terms of broadband speeds. ${ }^{27}$ The UK's position could be enhanced with further investment, such as occurred in Sweden, where just 1.6 percent of people in 2007 lived in homes without wired broadband availability. The central reason for Sweden's almost ubiquitous wired broadband coverage is that during the last economic downturn the Swedish government allocated $f^{5} 558$ million to stimulate the broadband infrastructure rollout, including $£ 170$ million in grants to communities to build local broadband networks, both in the towns and in the surrounding countryside, and $f_{170}$ million in tax incentives, amounting to 50 percent of the cost to build the network. $^{28}$

The improving conditions in the UK should not lead to complacency; not only does the UK lag behind the broadband leaders, but the fragility of the rates of improvements are clearly apparent in many countries, most especially in the United States. In 2009, without the additional investment in broadband infrastructure that can be spurred through investment (whether in the form of tax incentives, grants, or other means), private-sector broadband infrastructure investment in the United States is likely to fall from 2008 levels. For in the U.S., as UBS Warburg notes, capital expenditures by telecom and cable firms are expected to decline by 10 percent, if not more, in 2009 (in the absence of a federally-driven effort to stimulate broadband investment). ${ }^{29}$

For these reasons, LSE and ITIF propose a three-tiered set of investment incentives focused on addressing the three primary broadband policy goals: (1) getting broadband to unserved areas; (2) expanding network speeds in areas currently served by just first-generation broadband (3 Mbps or less); and (3) spurring increased adoption of broadband by households. These investments could take the form of temporary tax incentives for broadband buildout, especially to unserved areas, grants for buildout and adoption, and perhaps as NESTA has proposed, investment commitments tied to increased spectrum availability.

\section{Broadband: Impact on Employment}

To assess the impact of the incentives just described, LSE and ITIF estimate the jobs created or retained by an additional $£ 5$ billion investment in broadband. Any package that spurred more investment would result in the creation of additional jobs. 
LSE and ITIF estimate that incentives that spur a $\$ 5$ billion investment in broadband network infrastructure would lead to the creation of over 280,000 jobs.

Direct jobs are created in the telecommunications industry as additional frontline technicians are hired (or existing ones retained) to install broadband networks and employees are hired or retained to fill back-office functions, from managers to customer service representatives. Approximately 50 percent of the cost of deploying fibre optic broadband is in the labour component. ${ }^{30}$ The labour cost to deploy digital subscriber line (DSL) or cable broadband service tends to be less than deploying fibre to the home (FTTH) because DSL and cable entails more retrofitting of existing lines with capital equipment. Stephen Pociask, president of TeleNomic Research, has estimated, for example, that "telephone plant requirements (for broadband installation) consist of 28 percent capitalised labour." 31 Assuming 75 percent of broadband investment goes to fibre and 25 percent goes to phone-based DSL service or cable-based broadband, this report finds that a $£ 5$ billion investment in broadband would create about 76,500 direct jobs in the telecommunications and cable industries.

Broadband creates jobs by enabling the emergence of new businesses or other organisations developing a wealth of innovative new services, including electronic commerce, telemedicine, VoIP (Voice over Internet Protocol), video on demand, smart homes, telework, and access to electronic government.

With roughly 45 percent of the cost of broadband deployment in labour (given the mix of cable-, fibre optic-, and phone-based broadband deployment presented here), the balance of the cost -55 percentis in capital equipment: that is, the fibre optic cable, routers, servers, switches, and related computer equipment. Jobs are created in the industries that manufacture these products as demand increases for the telecommunications, electronic, and computer equipment ("capital equipment") needed to deploy broadband. For broadband roll-out, 34 percent of the cost to the equipment supplying firms is in workforce compensation. ${ }^{32}$ While most of that equipment manufacturing remains in the UK, around one quarter is likely to "leak out" to jobs outside of Britain. ${ }^{33}$

Approximately 94,000 of the jobs generated from a $£ 5$ billion broadband investment would be created within small firms with fewer than 250 employees. Many of the direct telecommunication jobs created for small businesses would be for sub-contractors to the telecommunications companies. Much of the investment to deploy faster broadband networks or bring service to unserved areas would be made by large cable and telecom firms like BT and Virgin. However, telecom and cable firms commonly hire third-party outside plant subcontractors for the physical installation of broadband. Many third-party outside plant subcontractors are small to medium-sized enterprises that specialise in installing physical infrastructure, such as the road and pavement work needed to install fibre conduits and cables.

\section{Broadband: Network Effect}

The increased deployment of broadband infrastructure creates a network effect that spurs additional job creation. The reason is that broadband itself increases business productivity, spurs upstream investment (e.g., of higher speed computer equipment), and contributes to the creation of new industries. We expect a network effect multiplier of 0.33 to boost the effect of new investment in broadband, a conservative estimate given previous studies finding a greater network multiplier for broadband. ${ }^{34}$

Broadband encourages upstream investment in industries creating new and innovative applications and services such as telemedicine, Internet search, ecommerce, online education (distance learning), and social networking. As an example, household broadband adoption has been found to spur the purchase of new and more powerful computers: there is a moderately strong correlation between computer speeds and broadband penetration rates (0.41) in the United States, indicating that as areas increase access to high-speed Internet connections, consumers are more inclined to upgrade their personal computers and other Internet- 
based devices. ${ }^{35}$ Broadband also spurs consumer purchases of additional computer peripheral equipmentfrom web cameras to gaming consoles to computer speakers. ${ }^{36} \mathrm{~A}$ recent study by the Fiber-to-the-Home Council in the United States found evidence of broadband's network effect in spurring consumption of new computers, high-definition televisions, and peripheral computer equipment, concluding that the average amount of new consumer electronics purchased by each FTTH broadband subscriber was $\$ 370.50 .{ }^{37}$

More importantly, broadband creates jobs by enabling the emergence of new businesses or other organisations developing a wealth of innovative new services, including electronic commerce, telemedicine, VoIP (Voice over Internet Protocol), video on demand, smart homes, telework, and access to electronic government. The network effect as it pertains to broadband is not simply about the value of the network increasing as more people join the network; it is also that by providing an architecture for the seamless and instantaneous creation, distribution, and consumption of information, it enables forms of commerce on a national and global scale previously impossible, transforming whole industries from retailing, to financial services, to manufacturing.

Broadband makes possible new business models that leverage the aggregation of both supply and demand, with the ensuing scale driving prices down and expanding consumer choice. Thus, for example, eBay aggregates both supply and demand to create an electronic auction marketplace for consumer goods, creating "prosumers" by turning consumers into producers. Similarly, WhizzGo and Zipcar make fractional ownership possible by aggregating demand for shortterm rental of vehicles in one venue, providing a viable alternative to, and decreasing the need for, auto ownership in congested cities. Other business models exemplifying the network effect and made possible by high-speed broadband connections include the mass customisation of products through the Internet, such as Dell and HP's build-to-order PCs or personalized Mini Coopers, and the marketing of excess capacity through Lastminute.com and Priceline.com. The latter are variants of web-enabled just-in-time manufacturing practices that have revolutionized global supply chains in industries from aircraft and automobile manufacturing, to wholesale and retail trade, to logistics.
It is this ability of high-speed broadband to create the conditions, the fertile soil, that generates entirely new upstream industries which is perhaps the most important component of the network effect. The resulting deployment of innovative services, applications, and content enhances communications, entertainment, health care, education, job search, and professional skills development, delivering substantial consumer benefits, increasing business productivity, and spurring economic growth. ${ }^{38}$ And, as we discuss below, a number of studies have found significant employment gains from broadband investments. In some cases, the number of jobs created by the upstream network effect can be as great as or even greater than the number of direct and indirect jobs created from the initial investment.

Research in America from the Brookings Institution confirms the presence of the network effect multiplier for broadband. Brookings found that for every 1 percentage point increase achieved in broadband penetration, employment rises from 0.2 to 0.3 percent. ${ }^{39}$ If applied to the British context, that translates to approximately 60,000 new UK jobs for an economy at less than full employment. ${ }^{40}$ The Brookings study found that "the effect of broadband is most significant in explaining employment growth in education, health care, and financial services, and was also significant in the 2003-05 growth of manufacturing employment." ${ }^{\prime 41}$

Although network effects do decline with the buildout of networks and maturing technology over time, there is still considerable opportunity for network effects stemming from broadband investments because more than 40 percent of UK residents still do not subscribe to broadband Internet. In addition, most of those accessing the Internet via broadband do so at much slower network speeds than citizens in Japan, France, South Korea, and Sweden. ${ }^{42}$

Broadband access is also critical to economic and employment growth in communities and regions throughout the country. ${ }^{43}$ One American study found, for example, that over a 4-year period from 1998 to 2002, employment in U.S. communities with broadband grew one percentage point more than in communities without it. ${ }^{44}$ This means that a community with 50,000 jobs with broadband would have added 500 more jobs over 4 years than a similar community without broad- 
band. Broadband is also an excellent source of highskilled, high-paying jobs; indeed, jobs involved in the building and expansion of broadband networks pay well, around 40 percent higher in the United Kingdom than the average for manufacturing jobs. ${ }^{45}$

The impact on economic and employment growth from broadband is real and substantial. Communities and citizens that lack high-speed broadband Internet access are at a deficit in comparison to their peers; likewise, the lagging rate of national broadband penetration and slower speeds in the United Kingdom places it at a deficit in comparison to peer countries. The Government is justified in supporting efforts to build up the UK's digital infrastructure, much as it did in past centuries with rail, highway, and telephone infrastructure. Supporting efforts to build up the UK's broadband infrastructure will deliver considerable employment gains and provide lasting improvements to business productivity and enduring consumer benefits that raise the quality of life by enabling telecommuting, telemedicine, entertainment, access to e-government, and a wealth of other online services.

\section{INTELLIGENT TRANSPORTATION SYSTEMS (ITS)}

We estimate that spurring $£, 5$ billion of investment in intelligent transportation systems (ITS) would support approximately 188,500 new or retained jobs for a year (see Table 3).

ITS is the integration of information and communications technology with transport infrastructure, vehicles and users. By sharing vital information, ITS allows people to get more from transport networks, in greater safety and with less impact on the environment. Only once travellers, vehicles and infrastructure can freely exchange information will the performance of the transport network be fully optimised.

Applying ICT to the UK's transportation system in the form of intelligent transportation systems will deliver five key classes of benefits by: 1) increasing driver and pedestrian safety; 2) improving the operational performance of a country's transportation network; 3) enhancing personal mobility and convenience, especially through provision of real-time traffic information; 4) delivering environmental benefits through alleviating congestion and streamlining traffic flow; and 5) boosting productivity and expanding economic growth.

1. Increasing driver and pedestrian safety. While intelligent transportation systems will yield important mobility, productivity, and environmental benefits, they can also increase traveller safety. There were almost 43,000 deaths on European Union roadways in 2006, of which just over 3,000 were in Britain. ${ }^{46}$ Roadway accidents impact hundreds of thousands of lives and cost the European economy around $€ 200$ billion each year. A wide range of ITS-based applications have safety as a principle focus, seeking to either outright reduce traffic accidents and the damage caused by them.

\section{Improving the operational performance of the} transportation network. As the Eddington Commission Report demonstrated, deploying intelligent transportation systems, such as congestion pricing, can dramatically improve the performance of a country's transportation network by maximizing the capacity of existing infrastructure, reducing the need for additional road capacity. ${ }^{47} \mathrm{~A}$ number of ITS technologies contribute to combating congestion, the scourge of many UK roadways. Congestion costs the UK economy dearly, as 65 percent of schedule delays result from demand exceeding capacity and excessive stop/ start traffic ${ }^{48}$, in contrast to only 10 percent of delays that result from road works, and 25 percent from accidents and other incidents. ${ }^{49}$ Several ITS technologies have demonstrated considerable ability to reduce congestion in their thus far limited deployment in the UK. Deploying these technologies nationwide would simultaneously spur employment, reduce congestion, benefit the environment, and deliver productivity increases that drive long-term economic growth. These technologies include:

- Adaptive traffic signal control has resulted in decreasing delays by 20 percent and vehicle emissions by 5 percent where it has been deployed, but adaptive traffic signal control has only been introduced at a small share of UK intersections.

- Ramp metering has contributed to an approximately 10 percent reduction in journey time on 
mainline routes through congested areas, but is yet to be widely deployed. ${ }^{50}$

- Active traffic management, including measures such as hard shoulder running (using shoulder lanes during rush hour), has contributed around a 10 percent reduction in emissions where deployed. $^{51}$

- Electronic toll collection can also significantly enhance traffic flow, as more than 30 percent of highway congestion occurs at toll stops, and if combined with tolls that vary with congestion, this can reduce peak traffic volumes, reducing congestion. $^{52}$

Electronic toll collection can also significantly enhance traffic flow, as more than 30 percent of highway congestion occurs at toll stops, and if combined with tolls that vary with congestion, this can reduce peak traffic volumes, reducing congestion. ${ }^{52}$

Intelligent transportation systems further enable transportation agencies to collect the data needed to measure and improve the performance of the transportation system. For example, ITS allow transportation agencies to collect data before and after construction projects to evaluate their effectiveness in relieving congestion. Deploying ITS technologies that contribute to more efficient traffic management should be a clear target of future ITS investments.

\section{Enhancing personal mobility and convenience.}

Perhaps the most familiar intelligent transportation systems are satellite-based vehicle navigation systems that provide route (navigation) guidance to drivers, and that may also (depending on the availability of data to information service providers) be able to provide driv- ers with real-time, in-vehicle information on congestion ahead and dynamically reroute the driver around traffic. These services help drivers identify and take the most efficient routes, avoiding congestion or road work, preclude motorists from getting lost, and can even alert the driver in real-time on a context-specific basis of roadway hazards. As we explain subsequently, there are robust growth opportunities for these services in the United Kingdom.

4. Delivering environmental benefits. Intelligent transportation systems are positioned to deliver important environmental benefits by reducing congestion, enabling traffic to flow more smoothly, coaching motorists how to drive most-efficiently, reducing the need to build additional roadways by maximizing the capacity of existing ones, and improving the performance and reliability of mass transit. Vehicle transportation is a major cause of greenhouse gas emissions. In England, the transport sector contributes around a quarter of the country's $\mathrm{CO} 2$ emissions, 93 percent of which is from road transport. ${ }^{53}$

Traffic congestion causes an outsized amount of $\mathrm{CO} 2$ emissions; for example, a vehicle travelling at $60 \mathrm{~km} / \mathrm{h}$ emits 40 percent less emissions than one travelling $20 \mathrm{~km} / \mathrm{h}$ or below. Thus, intelligent transportation systems that decrease congestion and improve traffic flow have a considerable ameliorating environmental impact.

5. Boosting productivity and economic growth. Finally, intelligent transportation systems boost productivity and expand economic growth. As demonstrated, ITS can provide significant economic impacts by improving the performance of the UK's infrastructure and enhancing the productivity of its workers and

TABLE 3: UK JOBS CREATED OR RETAINED FOR 1 YEAR BY A £5 BILLION ITS INVESTMENT

\begin{tabular}{l|c|c} 
Job Type & Total Jobs & Small Business Jobs \\
\hline Direct & 62,500 & 44,000 \\
Indirect \& Induced & 79,000 & 53,000 \\
Network effect & $\mathbf{4 7 , 0 0 0}$ & 23,000 \\
Total Jobs & $\mathbf{1 8 8 , 5 0 0}$ & $\mathbf{1 2 0 , 0 0 0}$
\end{tabular}


businesses. ITS further indirectly benefits the economy by reducing traffic accidents, injuries, and fatalities. London's experience with congestion zone pricing (itself a rather sophisticated technical achievement) is a model of this, and even if it may not soon be replicated in Manchester or elsewhere, it stands as a demonstration of the potential efficacy of one particular kind of approach to ITS. By 2006, traffic levels in London's original congestion zone had declined 21 percent since the scheme's introduction in $2002 .{ }^{54}$ Congestion charging was also estimated to have directly reduced about 16 percent of $\mathrm{CO} 2$ emissions from traffic within the charging zone. ${ }^{55}$

With its well-developed wireless high-speed network, Britain is well positioned to capitalise on the growing importance of communication services within the ITS market in the coming years.

ITS can also directly benefit economic growth by stimulating high-tech job creation across multiple sectors, including green jobs, high-tech, automotive, information technology, consumer electronics, and many related industries. A number of countries, including South Korea, Germany, and Japan, view their intelligent transportation systems industry as a key industrial base or sector, and one capable of generating considerable export-led economic growth. ${ }^{56}$

The primary categories of ITS products and services in the UK are network management, including, but not limited to, road user charging; automotive and freight telematics, including on-board vehicle navigation and real-time traffic information systems; and security enhancement and crime reduction technologies including closed circuit television (CCTV) and automatic number plate recognition (ANPR) used in service of road or congestion pricing initiatives. ${ }^{57}$ The UK also has expertise in technology for stolen vehicle tracking, largely due to insurance company requirements for these systems.

The base upon which further growth can be built in the UK is strong. With its well-developed wireless high-speed network, Britain is well positioned to capitalise on the growing importance of communication services within the ITS market in the coming years. Although the Department for Transport has proposed to bring forward some of the currently-budgeted medium term investment, there is justification for additional investment in the near term. ${ }^{58}$ Investment in ITS would accelerate existing plans and extend pilot projects that are increasingly regarded as priorities by the Department for Transport, Transport for London, the Metropolitan Authorities and numerous country councils.

\section{ITS: Impact on Employment}

A $£ 5$ billion per year additional investment in ITS would generate approximately 188,500 new or retained UK jobs for a year (see Table 3). Approximately two-thirds of the jobs created by ITS investments are in small businesses. The high number of small business jobs is a result of the fact that much of ITS investments go to software development and services. In addition, the geographical distribution of the road network means that skilled jobs would be created all over the country, supporting communities with a diverse work force.

The economic impact of investments in ITS may vary based on the specific project which generally can be categorized as either a vehicle-centred or an information-centred investment. Typically vehicle-centred investments focus on receiving, emitting and processing data and payments, through antennas, GPS, and onboard servers on buses, trams, and regional trains. Typical examples of information-centred projects include route optimisation and real-time updates (distributed either to proprietary onboard systems or to web applications for PC and mobile phone access), or signal optimisation, such as coordinating traffic lights with prioritised public vehicles in city traffic. We developed a model of likely spending in hardware, software and services and interviewed leading U.S., UK, and European experts on ITS projects to validate our findings ${ }^{59}$ Finally, we used these estimates to calculate the number of direct jobs in each of these industries based on the estimated percentage of spending on labour and the average labour costs, using data from the UK Office for National Statistics. ${ }^{60}$

We estimate that approximately 62,500 of these jobs would be created directly by investment on ITS proj- 
ects. In addition, almost 79,000 jobs would be created from spending on the intermediate inputs involved in producing the hardware, software and services needed to develop and implement ITS projects, and new spending by all of the additional workers employed by these investments.

\section{ITS: Network Effect}

Investment in intelligent transportation systems in the United Kingdom will likely contribute to additional job growth in related industries (i.e., the network effect) because ITS will spur the development of new products and services. The net impact of these network effects cannot be precisely quantified; however, a conservative estimate would be to expect at least an additional 33 percent employment gain, or approximately 47,000 jobs.

The network effects from intelligent transportation systems stem from the new applications that will be developed to take advantage of a more intelligent transportation infrastructure. As ITS technologies turn vehicles into mobile information platforms, ITS enable new consumer products and services that provide drivers with travel and traffic information such as transit routes and schedules, navigation directions, and projected delays due to congestion, accidents, weather conditions, or road repair work. Examples include incar navigation systems (which become more valuable to the consumer if enabled with ITS), real-time traffic information services, and communication services. One such application already deployed is "eCall", a service whereby vehicles in an accident trigger an automated emergency call (E112) to the closest Public Safety Answering Point or emergency call centre. eCall is an in-vehicle service that combines GPS location with airbag sensors and mobile phone technology to automatically alert the emergency services to the location of an accident. The UK public emergency system is currently capable of receiving and handling these E112 calls. ${ }^{61}$ This type of in-vehicle service may drive consumer demand for the BMW and Volvo systems available in Britain (which are comparable to General Motors' OnStar system), that offer a range of safety, crash notification, and concierge services including location-based services, mobile calling, and in-vehicle entertainment like movie downloads.
Many drivers now print driving directions in advance of their trip or use a satellite-based in-vehicle navigation system for route guidance. The next step is marrying static route guidance technology with real-time traffic-status information on congestion, accidents, and road works or closures, dynamically generating for drivers optimal navigation guidance based on realtime traffic conditions. As intelligent transportation systems fundamentally make possible these new and novel services, they exemplify the network effect at work. Moreover, just as a wealth of companies have arisen to provide location-based services (LBS) to the mobile phone, so will many vehicle-attuned LBS services arise, enabling motorists to search for, find, and navigate to nearby restaurants, accommodations, attractions, etc.

Japan's use of intelligent transportation systems to revitalize regional economies is another example of the ITS network effect at play. A number of regional promotion councils in Japan have developed "tourist ITS systems," which provide tourist information alongside road traffic information to entice travellers to visit regional attractions. ${ }^{62}$ Drivers in Britain have long used maps and guidebooks provided by the Automobile Association (AA). As those static guidebooks give way to up-to-the-minute information delivered through the vehicle's on-board navigation system, new opportunities arise for communities and merchants to attract visitors to their establishments and attractions. ITS in Japan also enabled the spread of mobile commerce. For example, Japan instituted a single national standard for automatic electronic toll collection (ETC), and then empowered private companies to offer automatic payment options to customers via the same ETC standard. Popular ETC-based applications in Japan include automated payment of parking lot fees, automatic payment at gas stations, and simplified boarding procedures at ferries. ETC technology is even used in Japan to help store managers recognise when regular customers are returning to their store, enabling them to offer targeted promotions, or prepare services in advance.

ITS delivers network effect benefits to the commercial world as much as the consumer. ITS further enables electronic freight management, allowing logistics companies to provide real-time status information of their customer's shipments and empowering just-in-time 
logistics networks. For example, in the United States, the firm Total Quality Logistics grew from a start-up in 1997 to an almost $\$ 1$ billion company in just over a decade in part by providing clients real-time information on full-truckload third party logistics shipments. ${ }^{63}$ Likewise, intelligent transportation systems are positioned to unlock a wave of innovation in the United Kingdom's logistics industries.

Clearly then, a major investment in ITS in the United Kingdom would generate both sizeable employment gains, advances in the national transportation infrastructure and related benefits including reduced congestion, fewer accidents, improved mobility, and reduced energy consumption and emissions. All of these benefits would contribute to increased productivity, a more efficient and environmentally friendly transportation system, and a stronger economy for workers and businesses. ${ }^{64}$

\section{SMART GRID}

We estimate that spurring $£, 5$ billion of investment in the smart grid would support approximately 231,000 new or retained jobs for a year (see Table 4).

Although today's power grid has greatly expanded from its origins in the London Electric Supply Corporation's Deptford Power Station, many of its components and overall design would be familiar to its architect, Sebastian de Ferranti, were he alive today. Although electrical power has been harnessed for uses inconceivable a century ago, and the United Kingdom consumes around 62 gigawatt-hours (GWh) of electricity annually, the networks that distribute this power have not kept pace. ${ }^{65}$ Indeed, although the power grid is the cornerstone of modern life, from industrial manufacturing to the ICT revolution to everyday conveniences, relatively few upgrades have occurred in our transmission and distribution infrastructure.

The central idea behind modernising the power grid's infrastructure is to use two-way communication, sensors, and advanced ICT to create an intelligent and connected power grid-that is, the "smart grid." The smart grid is intended to be a revolutionary network, much like the Internet, that will deliver power more efficiently and more reliably than our existing grid.
With the smart grid, utilities can utilise real-time data from sensors and advanced meters throughout the power grid to understand better specific supply and demand requirements, spot failed or failing equipment, and better manage their resources. The role of ICT in smart grids includes the adoption of ubiquitous automation systems, sensors and monitoring devices (smart sensors), data collection systems and communications systems. ${ }^{66}$

The smart grid is intended to be a revolutionary network, much

like the Internet, that will deliver power more efficiently and

more reliably than our existing grid.

The smart grid will enable a host of societal benefits including lowering peak demand and the associated costs and electricity generation, enabling the greater use of clean energy, and providing electricity more reliably. Moreover, the smart grid will enable the use of new technologies including plug-in hybrid electric vehicles, distributed generation, and energy storage solutions.

Historically, peak demand for power has grown faster than overall demand-a challenge for electric utilities. To satisfy peak demand, utilities must bring online additional generators, or peaker power plants, which are generally more expensive to operate and produce more pollution. In the United States, reducing peak demand could generate substantial savings: for example, reducing peak demand by 5 percent would save $\$ 31$ billion over 20 years. ${ }^{67}$ Britain enjoys the advantage of being linked in to the Continental grid through France, and load spreading, through use of French nuclear-generated power, alleviates some of the problem. However, the smart grid enables a variety of demand response options for consumers targeted specifically at this problem.

One step the United Kingdom could take to develop the smart grid would be to deploy an advanced energy-metering infrastructure-i.e., "smart meters"- to UK residences and businesses. Smart meters encourage energy efficiency in part by allowing consumers to determine their energy usage based on dynamic price 
signals that fluctuate throughout the day in response to energy supply conditions or at certain times of critical peak demand. At a basic level, smart meters can simply cycle off a major appliance, such as an air conditioner, for a short interval at peak periods of the day. In addition, consumers can choose to operate certain appliances (e.g. washing machines, dishwashers, etc.) at off peak hours. On a more advanced level, smart meters can interface with smart appliances, so that, for example, a refrigerator will wait until the evening to run its defrost cycle or a clothes dryer will turn off its heating element when drying clothes on a hot afternoon. By responding to price signals, consumers can help reduce peak demand and their own energy costs. In one pilot program in the United States, for example, participants using smart meters saved on average 10 percent on their utility bills. ${ }^{68}$ Utilities also save money from smart meters by automating functions such as meter reading and connecting and disconnecting service.

The smart grid will also lead to a number of additional cost savings by making electricity transmission and distribution in the United Kingdom more reliable and efficient. Without the smart grid, for example, a utility will not know that a customer has lost power unless the customer reports the outage. The costs of these outages are substantial: the RAND Corporation and the Electric Power Research Institute have estimated that outages in the United States cost businesses as much as $\$ 100$ billion per year. ${ }^{69}$ Better sensors throughout the grid will give utilities more situational awareness and allow grid operators to repair damage more efficiently and anticipate potential problems earlier.

We also note that additional investment in the smart grid is in line with national objectives to increase the security and reliability of critical infrastructure such as the power grid. Modernising our power grid will not only create a more robust and resilient grid, it will also allow utilities to improve their grid control systems and reduce their vulnerability to cyber threats.

The electricity sector in the EU has an annual turnover of over $€ 115$ billion and contributes about 1.5 percent to EU GDP. ${ }^{70}$ Looking ahead, EU Member States will need to invest in excess of $€ 750$ billion in power infrastructure over the next three decades, divided equally between generation and networks (some $€ 90$ billion will be invested in transmission and $€ 300$ billion in distribution networks). Much of this investment would be needed regardless of whether the power grid was smarter or not, but moving to a smart grid could help reduce the magnitude of the needed investment in new capacity.

Some 15,000 households have had smart meters installed in the UK, many with both gas and electricity smart meters (as of end 2008). The Government allocated $£ .9 .75$ million to partially finance a large-scale trial investigating consumer response to improved feedback on their energy use-the Energy Demand Research Project (EDRP). The EDRP is required to submit reports at six-monthly intervals for the duration of the project. The EDRP is being undertaken by four different energy companies, namely EDF Energy Customers plc (EDF), E.ON UK plc (E.ON), SSE Energy Supply Limited (SSE) and ScottishPower Energy Retail Limited (SP). ${ }^{71}$

The unit cost of smart meters should drop with economies of scale and as the technology becomes more mature. In addition, there is a wide spectrum of options for smart meters, each with varying costs and benefits. For example, some utilities may invest in low-end smart meters with limited functionality, such as hav-

TABLE 4: UK JOBS CREATED OR RETAINED FOR 1 YEAR BY A £5 BILLION SMART GRID INVESTMENT

\begin{tabular}{l|c|c} 
Job Type & Total Jobs & Small Business Jobs \\
\hline Direct & 43,000 & 26,500 \\
Indirect \& Induced & 130,500 & 91,000 \\
Network effect & 57,500 & 28,500 \\
Total Jobs & $\mathbf{2 3 1 , 0 0 0}$ & $\mathbf{1 4 6 , 0 0 0}$
\end{tabular}


ing a remote connect/disconnect function or providing automated meter reading, while on the other end of the spectrum a more advanced smart meter could integrate with a home network, "talk" with household appliances and provide other consumer and societal benefits. $^{72}$

It is important to recognise that building the smart grid will require much more than just investment in smart meters. Utilities must implement ICT throughout their entire operation, from advanced back office servers to automating substations to integrating renewable energy sources into the existing grid. ${ }^{73}$ Communication networks must be integrated with the system, such as through wired broadband, including over power lines, fibre-optic cables, cellular networks, or WiFi. At the end-points, consumers must implement tools, such as smart thermostats, smart appliances, and other energy management tools. In the near to mid-term, investments in the British smart grid will be for advanced metering at large commercial and industrial facilities, smart metering for residences and small businesses, and better grid network intelligence, including broadband over power lines, intelligent electronic devices, and advanced distribution protection and restoration devices. ${ }^{74}$

Given the difficult economic conditions in the United Kingdom today, in the short term, it is likely that many utilities will avoid investing in ICT projects as a result of the tight credit market and reduced economic activity. Without access to sufficient credit, some smart grid projects will likely be scaled back, postponed, or eliminated. One important contribution of including a smart grid investment in an economic investment programme and adopting regulations to promote investment is to ensure that work on existing and proposed smart grid projects continue.

\section{Smart Grid: Impact on Employment}

A $£ 5$ billion per year additional investment in smart grid would generate approximately 231,000 new or retained UK jobs for a year (see Table 4). Approximately sixty percent of the jobs created by this investment would be in small businesses.

We estimate that an additional investment of $£ 5$ billion per year in smart grid would create approximately 173,500 direct, indirect and induced jobs. As others have noted, building the smart grid requires a diverse workforce from the meter and power line installers to build the network to software engineers and administrators to run the network. In addition, manufacturers must produce the computer systems, networking devices, sensors, and meter hardware used to run the smart grid by employing machinists, team assemblers, and technicians. ${ }^{75}$

Building the smart grid requires a diverse workforce from the meter and power line installers to build the network to software engineers and administrators to run the network.

To calculate our projection, we created a model to estimate spending in construction, hardware, software, and services related to smart grid and smart metering. We developed this model using data from KEMA Inc. of a planned smart grid project in the United States ${ }^{76}$ and data from the UK Department for Business, Enterprise and Regulatory Reform (BERR) of costs estimates for a 10-year roll out of smart meters throughout the UK. ${ }^{77}$ Using standard UK import and product data, we estimated the percentage of investment in each industry to be outsourced to foreign firms. ${ }^{78}$ Investment in grid construction involves adding new wires, and includes design, construction, equipment, and labour. This investment also includes upgrades to the transmission and distribution lines and repairs due to aging and weather. Hardware expenditures include smart meters, substation automation equipment, networking equipment and servers. Software investments include items such as meter system interfaces, network automation and control, analytics, and web-enabled consumer applications. Expenditures on services consist of spending on systems integrating, customer equipment installation and other ICT services.

It is important to note that by spurring investment in the smart grid and its intermediate inputs, the United Kingdom not only will reap savings in energy efficiency and benefit from new innovations in green technology but will also create a market for these components and technical services to domestic firms. Investing in the smart grid now will help ensure domestic firms have the knowledge, skills, and abilities needed to become chief exporters of this technology as other coun- 
tries expand their own smart grid initiatives. Thus, an investment in the smart grid, in addition to spurring short-term job growth in the United Kingdom, will enhance the nation's long-term competitiveness and increase the number of higher value-added jobs.

\section{Smart Grid: Network Effect}

Building infrastructure like the smart grid will not only create direct employment from government investment, indirect employment from downstream inputs to the utility industry, and additional jobs from respending, but it will also create new jobs as related industries grow to take advantage of the new technology. We estimate an additional 57,500 jobs would be created from the network effect enabled by the smart grid. $^{79}$

The smart grid provides many examples of the network effect. For example, the smart grid will encourage appliance manufacturers to produce new appliances that not only use energy efficiently, but also use it more intelligently. As a result, this may lead some consumers to upgrade old appliances more quickly, and other consumers may buy more smart refrigerators and fewer less expensive "dumb" refrigerators. But these advances also create an ecosystem of related products and services-for example, home networking kits to connect smart appliances to the Internet, software applications to interface with the appliances, and online services that take advantage of new digital information and wired appliances (e.g., tracking the expiration date on food).
The smart grid will enable new products and services that cannot be deployed without this infrastructure. Many new technologies depend on the smart grid, from plug-in hybrid electric vehicles ${ }^{80}$ to energy storage solutions to home automation and commercial building intelligence. In addition, the smart grid will facilitate distributed generation and encourage the development of renewable energy sources, such as wind farms. Eventually, the smart grid will even create an energy marketplace where businesses and homeowners can sell energy back to the grid, enabling even more innovation. This will in turn spur consumer demand for products such as rooftop solar panels for their home. Indeed, the smart grid will likely serve as the foundation for the growth of many new industries much like broadband is creating new markets in e-commerce, telehealth, and online banking.

With growing concern about energy efficiency, carbon emissions, and energy independence, modernising our national power grid infrastructure represents an important investment opportunity for the UK's future.

\section{CONCLUSION}

Government has an opportunity to stimulate investment in ICT to ease the burden of the current economic downturn. Spurring investments in ICT infrastructure not only can provide an important short-term boost to the UK economy; it also can lay the groundwork for long-term economic growth, international competitiveness, and significant improvement in quality of life. ${ }^{81}$ 


\section{ENDNOTES}

1. Department for Culture, Media and Sport and Department for Business, Enterprise and Regulatory Reform; "Digital Britain: The Interim Report" January 2009 (Cm7548); James Meadway and Juan Mateos-Garcia, "Getting up to speed: making super-fast broadband a reality", NESTA Policy Briefing S-FB/33, January 2009; H.M. Treasury, "Budget 2009" < budget.treasury.gov.uk>.

2. A network effect is the effect that one user of a good or service has on the value of that product to other users. The value of the network increases logarithmically with each new user added to the network. The classic example is the telephone; the more people own telephones, the more valuable the telephone is to each owner.

3. A basic review of UK data on information and communication technologies can be found in the 2006 edition of the United Kingdom Input-Output Analyses, compiled by Sanjiv Mahajan and available through www.ons.gov.uk. See also: John Windhausen Jr., A Blueprint for Big Broadband, (Washington, D.C.: EDUCAUSE, January 2008), <net.educause.edu/ir/library/ pdf/epo0801.pdf>.

4. Consider that the net social rate of return on motorway capital was very high, about 35 percent, when the U.K. motorway system was first constructed in the 1960s, but as the network was built out, the rate of return from capital investments steadily declined until reaching about 10 percent in the 1980s. As the network was first built out, it enabled innovations like guaranteed expedited shipping (e.g., United Parcel Service), consolidated freight shipping, expansion of the automobile industry, and the growth of new communities alongside motorways. Incremental investments in motorway infrastructure at its current level of maturity are unlikely to engender these network effects. Such investments will not, for example, spur individuals to go out and purchase a new set of tyres or faster cars. Hence, investments in motorways or other physical infrastructure are capable of delivering only the traditional employment multiplier. For more discussion, see Theofanis P. Mamuneas and M. Ishaq Nadiri, "Highway Capital and Productivity Growth," Appendix A, in Economic Returns from Transportation Investment (Lansdowne, Virginia: Eno Transportation Foundation, Inc., 1996): 56 <www.fhwa.dot.gov/policy/otps/060320a/060320a.pdf> (accessed January 1, 2009).

5. UK 2008 Annual Survey of Hours and Earnings, Office of National Statistics < www.statistics.gov.uk/StatBase/Product. asp? $\operatorname{vnk}=15187>$.

6. The seminal paper for the UK on this is Nicholas Oulton, "ICT and productivity growth in the United Kingdom" Bank of England working paper no. 140, 2001 and published in the Oxford Review of Economic Policy 2002; 18:363-379; See also Stephen D. Oliner, Daniel E. Sichel, and Kevin J. Stiroh, "Explaining a Productive Decade," Finance and Economics Discussion Series Working Paper No. 2007-63, Federal Reserve Board, Washington, D.C., August 2007 < papers.ssrn.com/sol3/papers.cfm?abstract_ id $=1160248 \#>$ (accessed January 1, 2009).

7. Nick Bloom, Stephen Dargan, John Dowdy, John Van Reenen, "Management Practice \& Productivity: Why they matter," LSE Centre for Economic Performance and McKinsey \& Co. July 2007. Also, see Centre of Economics Performance at the London School of Economics. <www.cep.lse.ac.uk>.

8. Christine Zhen-Wei Qiang and Alexander Pitt. "Contribution of Information and Communication Technologies to Growth.” World Bank Working Paper 24; (Washington, D.C.:The World Bank, 2004).

9. Commission of the European Communities, Accompanying document to the "i2010 Annual Information Society Report 2007," COM(2007) 146 final Brussels, 2007 <ec.europa.eu/information_society/eeurope/i2010/docs/annual_report/2007/ sec_2007_395_en_documentdetravail_p.pdf> and Oliner, Sichel, and Stiroh, 2007 op. cit.,; and Kevin Stiroh, "Information Technology and Productivity: Old Answers and New Questions," CESifo Economic Studies 54 (3/2008):358-385 < cesifo. oxfordjournals.org/cgi/content/abstract/54/3/358> (accessed January 1, 2009).

10. Gustavo Crespi, Chiara Criscuolo, Jonathan Haskel, Information Technology, Organisational Change and Productivity Growth: Evidence from UK Firms, February 2008, <www.lse.ac.uk/collections/MES/pdf/IT_OC_PG_Feb08_CC.pdf>. 
11. London School of Economics, Centre for Economic Performance, "Americans Do I.T. Better: US Multinationals and the Productivity Miracle", (London, UK: London School of Economics) <cep.lse.ac.uk/pubs/download/dp0788.pdf> (accessed April 22, 2009).

12. Robert D. Atkinson and Daniel Castro, Digital Quality of Life: Understanding the Personal and Social Benefits of the Information Technology Revolution (Washington, D.C.: Information Technology and Information Foundation, October 1, 2008) <www.itif.org/ index.php?id=179> (accessed January 1, 2009).

13. HM Treasury, Budget 2008; Stability and opportunity: building a strong, sustainable future; Economic and Fiscal Strategy Report and Financial Statement and Budget Report, March 2008 (London, UK: The Stationary Office) 2 <www.hm-treasury.gov.uk/bud_bud08_ repindex.htm>.

14. Ibid, p. 41. See pp. 48-50 on science and innovation, skills and infrastructure spending.

15. See the comments in the "Meeting the Aspirations of the British People", especially pp. 71 Comprehensive Spending Review 2007, (London, UK: HM Treasury)<www.hm-treasury.gov.uk/pbr_csr07_repindex.htm>.

16. Robert Crandall, William Lehr, and Robert Litan, "The Effects of Broadband Deployment on Output and Employment: A Cross-Sectional Analysis of U.S. Data," Issues in Economic Policy, No. 6, (Washington, D.C.: Brookings Institution, July 2007): $1<$ www.brookings.edu/ /media/Files/rc/papers/2007/06labor_crandall/06labor_crandall.pdf>.

17. Robert D. Atkinson, Daniel K. Correa, and Julie A. Hedlund, Explaining International Broadband Leadership (Washington, D.C.:Information Technology and Innovation Foundation, May 2008) < www.itif.org/index.php?id=142> (accessed January 1, 2009).

18. According to the U.S. Department of Transportation (U.S. DOT), an average of 50 percent of ITS project funding is spent on direct labor as compared to 20 percent for new highway construction, multiplying the economic benefits of ITS investments. See "Solutions to America's Transportation Challenges," (Washington, D.C.: U.S. Department of Transportation, 2009) <www. itsa.org/itsa/files/pdf/ITSAmericaAuthorizationProposalFINAL.pdf> (accessed April 9, 2009).

19. Our main sources included: ONS, The ONS Productivity Handbook edited by Dawn Camus, Palgrave Macmillan, 2007; ONS, United Kingdom National Accounts: The Blue Book. ONS 2008; ONS, United Kingdom Input-Output Analyses Edited by Sanjiv Mahajan 2006.

20. As the UK Office for National Statistics does not tracked employment multipliers, we estimated these values using the employment multipliers available from the Scottish Office. We adjusted the numbers to take account of the differences in the structure of the Scottish economy in relation to the rest of the UK and the economic growth between 2004 (the most recent data) and 2008.

21. Department for Business Enterprise \& Regulatory Reform (BERR), "Statistical Press Release" (London, UK: Department of Business Enterprise \& Regulatory Reform, July 2008) <stats.berr.gov.uk/ed/sme>. As of 2007 SMEs accounted for 51.5 percent of private sector turnover and employed 22.7 million people. SMEs in the UK are defined as those with fewer than 250 employees, as is the case with EU and OECD data, in contrast to the U.S. statistical sources that define SMEs as those with fewer than 500 employees.

22. James Meadway and Juan Mataos-Garcia, "Getting up to speed: making super-fast broadband a reality" NESTA Policy Briefing, January 2009 www.nesta.org.uk/assets/Uploads/pdf/Policy-Briefing/Getting_up_to_speed_NESTA_policy_briefing. pdf; Robert Crandall, William Lehr, and Robert Litan, "The Effects of Broadband Deployment on Output and Employment: A Cross-Sectional Analysis of U.S. Data," Issues in Economic Policy, No. 6, (Washington, D.C.: Brookings Institution, July 2007): 1 $<$ www.brookings.edu/ /media/Files/rc/papers/2007/06labor_crandall/06labor_crandall.pdf>. 
23. D'Costa and Kelly, "Broadband as a platform for economic, social and cultural development: Lessons from Asia," (Paris: OECD 2008); Broadband Stakeholder Group, "The impact of broadband-enabled ICT, content, application and services on the UK society and economy to 2010."

24. Crandall, Lehr, and Litan, “The Effects of Broadband Deployment,” op. cit., July 2007:6.

25. Robert D. Atkinson and Scott M. Andes, The Atlantic Century: Benchmarking EU \& U.S. Innovation and Competitiveness (Washington, D.C.: Information Technology and Innovation Foundation, February 2009).

26. Organization for Economic Co-operation and Development, "OECD Broadband Portal," $2008<$ www.oecd.org/documen t/54/0,3343,en_2649_34225_38690102_1_1_1_37441,00.html> (accessed April 12th 2009).

27. Julie Hedlund and Robert Atkinson, Explaining International Broadband Leadership (Washington, DC: Information Technology and Innovation Foundation, 2008).

28. Hedlund and Atkinson, "Explaining International Broadband Leadership", op. cit.

29. Dan O'Shea, "UBS Predicts 10 Percent Carrier Capex Cutback," FierceTelecom, December 3, 2008 <www.fiercetelecom. com/story/ubs-predicts-10-percent-carrier-capex-cutback/2008-12-03> (accessed January 1, 2009).

30. For specific detail, see Claudio Mazzali, Robert Whitman, and Bernhard Deutsch, "Optimization of FTTH Passive Optical Networks Continues," LightWave, January $2005<$ lw.pennnet.com/display_article/219598/13/ ARTCL/none/none/1/Optimization-of-FTTH-passive-optical-networks-continues/> (accessed January 1, 2009).

31. Stephen B. Pociask, "Building a Nationwide Broadband Network: Speeding Job Growth," TeleNomic Research, LLC, Herndon, Virginia, February 25, $2002<$ www.newmillenniumresearch.org/event-02-25-2002/jobspaper.pdf> (accessed January 1, 2009).

32. Robert Atkinson, Daniel Castro and Stephen Ezell, "Digital Road to Recovery: A Stimulus Plan to Create Jobs, Boost Productivity and Revitalize America" (Washington, DC: Information Technology and Innovation Foundation, 2009) <www.itif. org/files/roadtorecovery.pdf> (accessed April 22).

33. UK Office of National Statistics (ONS), "Latest I-O Data," 2009 <www.statistics.gov.uk/about/methodology_by_theme/ inputoutput/latestdata.asp> (accessed April 22, 2009).

34. Robert Crandall, Charles Jackson, and Hal Singer, The Effects of Ubiquitous Broadband Adoption on Investment, Jobs, and the U.S. Economy, (Washington, D.C.: Criterion Economics, LLC, September 2003): 21-22. <www.newmillenniumresearch.org/archive/ bbstudyreport_091703.pdf> (accessed January 1, 2009).

35. Broadband penetration data is taken from the Federal Communications Commission and is based on the percent of households that have a broadband connection. Personal computer speed data is from PC Pitstop's PC RAM diagnostic tests. Federal Communications Commission, "High-Speed Services for Internet Access: Status as of June 30th, 2008" (accessed December 16, 2008). PC Pitstop Research, “U.S. State Technology Metrics—Quartile Rankings,” n.d. <www.pcpitstop.com/ research/statetechrank.asp> (accessed December 16, 2008).

36. Joe Savage and Michael Render, "Community Benefits Resulting From Deployment of Fiber to the Home in the USA," (Portland, Oregon: FTTH Council, August 2006) <www.ftthcouncil.org/documents/728478.pdf> (accessed January 8th, 2008).

37. Ibid., 105. 
38. Pociask, "Building a Nationwide Broadband Network," op. cit., 2002:5.

39. Another study, performed in November 2007 by the Sacramento Regional Research Institute, reported that there was a "strong correlation between broadband growth in California and the number of new jobs available." The institute estimated that for every one percentage point of the adult population using broadband, the employment growth rate rises by 0.075 percentage points and the payroll growth rate also grows by up to 0.088 percentage points. Kristin Van Gaasbeck, Stephen Perez, and Ryan Sharp, "Economic Effects of Increased Broadband Use in California," (Sacramento, California: Sacramento Regional Research Institute, November 2007) <www.srri.net/AboutUs/EconEffectsBB_Research.pdf> (accessed April 24, 2009).

40. Crandall, Lehr, and Litan, “The Effects of Broadband Deployment,” op. cit., July 2007:2, 14.

41. Ibid., 12 .

42. Rob Atkinson, Stephen Ezell, Daniel Castro and George Ou, The Need for Speed (Washington, D.C.: Information Technology and Innovation Foundation, 2009) <www.itif.org/files/2009-needforspeed.pdf>.

43. Atkinson, "The Case for a National Broadband Policy," op. cit., June 2007.

44. William H. Lehr, Carlos A. Osorio, Sharon E. Gillett, et al., "Measuring Broadband's Economic Impact," presented at the 33rd Research Conference on Communication, Information, and Internet Policy (TPRC), September 23-25, 2005, Arlington, Virginia; revised as of January 17, 2006 <www.andrew.cmu.edu/user/sirbu/pubs/MeasuringBB_EconImpact.pdf> (accessed January 1, 2009).

45. UK Official of National Statistics, Annual Survey of Hours and Earnings (ASHE) 2008, <www.statistics.gov.uk/StatBase/ Product.asp?vlnk=15187> (accessed April 22 2008).

46. Department for Transport, "Road Casualties Great Britain", www.dft.gov.uk/pgr/statistics/datatablespublications/ accidents/casualtiesgbar/roadcasualtiesgreatbritain2005; BBC, “Annual Road Deaths at Record Low” news.bbc.co.uk/2/hi/uk_ news/7475893.stm; Frances Penwill-Cook, "Intelligent Transportation Systems: Driving into The Future," Road Traffic Technology, September 26, 2008 <www.roadtraffic-technology.com/features/feature42979/> (accessed April 4, 2009).

47. United Kingdom Department of Transportation, The Eddington Transportation Study," December 2006. <www.dft.gov. uk/about/strategy/transportstrategy/eddingtonstudy/> (accessed April 23, 2009).

48. Steve Tarry, Regional Director Faber Maunsell Presentation at World ITS Congress, New York, 2008 “The Role of Technology in Reducing Congestion and Transport Emissions" <www.ibec-its.co.uk/files/IBEC02-Tarry.pdf>.

49. Tarry, op. cit.

50. Tarry, op. cit.

51. Hard shoulder running provides additional capacity at times of heavy traffic and experience has shown that it can bring improvements in reliability and journey times. "In Holland, use of hard shoulder running has increased overall capacity at individual sites by between 7 percent and 22 percent." See "Annex to the DfT Advanced Motorway Signalling and Traffic Management Feasibility Study Report” (Washington, D.C.: Department for Transportation March 2008) <www.dft.gov.uk/pgr/ roads/network/policy/mtorsigntrafmanagement/technicalannex?page $=1>$.

52. Tarry, op. cit.

53. United Kingdom Parliamentary Office of Science and Technology, "Intelligent Transport Systems Postnote,” January 2009, Number 322. <www.parliament.uk/documents/upload/postpn322.pdf> (accessed March 30, 2009). 
54. Transport for London, "Congestion Charging four years on - traffic still down across central London," July 11, 2007 <www.tfl.gov.uk/corporate/media/newscentre/archive/5474.aspx> (accessed April 24, 2009).

55. Transport for London, op. cit.

56. Jeffrey Kim, "Strategies for Developing an Intelligent Transportation Systems Industrial Base in South Korea," (Cambridge, MA: Massachusetts Institute of Technology, 2003). <dspace.mit.edu/bitstream/handle/1721.1/30031/55087812. pdf?sequence $=1>($ accessed November 11, 2008).

57. innovITS, UK Centre of Excellence for Transport Telematics and Sustainable Mobility and Frost \& Sullivan, "Market Analysis of the Intelligent Transport Systems and Services (ITSS) Sector" (November 2008).

58. Department for Transport and Highways Agency, "Safe roads, reliable journeys, informed travelers; the Highways Agency Business Plan 2009-10," (Washington, D.C.: Department for Transport 2009);, “The Eddington Transport Study; The case for action: Sir Rod Eddington's advice to Government", December 2006, DfT.

59. Telephone and in-person interviews by authors include Stephan Hermansson, Senior ITS consultant, Gothenburg, Sweden; Business manager at Transport for London; Director, ITS UK; Business manager at UK Society of Motor Manufacturers and Traders Ltd. April 22, 2009; Jonathan Gifford, George Mason University on July 2, 2008; Richard Bishop, Bishop Consulting USA on November 13, 2008; Jerry Werner, former Director of the U.S. National Traffic Operations Center on November 13, 2008; Alvin Chiang, Singapore Intelligent Transport Systems Centre on November 16, 2008; Vinodh Swaminathan, IBM on April 13, 2009; and multiple representatives from ITS America, on November 12, 2008, January 6, 2009 and April 15, 2009.

60. ONS, 2008 Annual Survey of Hours and Earnings. Average labour costs are multiplied by 1.25 for construction, 1.30 for manufacturing, and 1.35 for software to reach industry total cost of labour. <www.statistics.gov.uk/articles/economic_trends/ ET627_Chesson.pdf>.

61. "eSafety Support: United Kingdom" eSafety Support. <www.esafetysupport.org/en/ecall_toolbox/eu_member_states/ united_kingdom.htm> (accessed on April 20, 2009).

62. Japan Highway Industry Development Organization, “ITS Handbook Japan 2007-2008,” 23.

63. Stephen Ezell and Timothy Ogilvie, "Seizing the White Space: Innovative Service Concepts in the United States," (Helsinki, Finland: Tekes, 2007) <www.tekes.fi/eng/publications/innovative_service.pdf> .

64. Scott Belcher, op. cit.

65. Data for 2007, Dept. for Business Enterprise \& Regulatory Reform, "Regional and local authority electricity consumption statistics: 2008, 2006 and 2007" <www.berr.gov.uk/energy/statistics/regional/regional-local-electricity/page36213.html> (accessed April 9, 2009).

66. "Increasingly, a smart grid is seen as a key enabler for the new energy economy and as such, is foundational for the millions of "green collar jobs" President-elect Obama is aiming for", said Guido Bartels, Gridwise Alliance Chairman in the USA

Transmission and distribution world, Jan 2009, 61, 1, p.14.

67. Ahmad Faruqui and Sanem Sergici, "The Power of Experimentation: New Evidence on Residential Demand Response," (Cambridge, MA: The Brattle Group May, 2008) <www.brattle.com/_documents/UploadLibrary/Upload683.pdf> (accessed January 1, 2009).

68. Barry T. Smitherman, Chairman, Texas Public Utility Commission, "Looking Towards the Future: Envisioning the NEW Electricity Industry," presented at UtiliPoint International's Fourth Annual North American Conference: How Smart is Your Utility? The Woodlands, Texas, October 16-17, 2008. 
69. Jesse Berst, "Macro Trends Point to Microgrids" SmartGridNews.com, November 28, 2006 <www.smartgridnews.com/ artman/publish/industry/Macro_Trends_Point_to_Microgrids_182_printer.html> (accessed January 1, 2009).

70. IEA “World Energy Investment Outlook 2003" < www.smartgrids.eu/documents/sra/sra_finalversion.pdf> (accessed April 22, 2009).

71. OFGEM (March 2009), Energy demand research project, Review of progress for period April 2008 - August 2008, <www.ofgem.gov.uk/MARKETS/RETMKTS/METRNG/SMART/Documents1/EDRP_Progress_Report_2.pdf> (Accessed April 22, 2009).

72. Rob Wilhite, "Value Drivers and Risk Factors for AMI Remote Disconnect/Reconnect Functionality," Automation Insight (published by KEMA, Arnhem, Netherlands), n.d. <www.kema.com/consulting_services/cross_sector/INC/Automation_ Insight/December_2007/value_drivers.asp> (accessed January 1, 2009).

73. Rick Nicholson and H. Christine Richards, "Who's Next, McDonald's? The Intelligent Grid Technology Landscape and Vendor Bandwagon,” EI213921, Energy Insights, IDC, Framingham, Massachusetts, August 2008 <www.idc.com/EI/getdoc. jsp?containerId=EI213921> (accessed January 1, 2009).

74. Zarko Sumic, Bradley Williams, Keith Harrison, et al., "Hype Cycle for Intelligent Grid Technologies, 2008,”G00158558, (The Netherlands: Gartner Consulting, June 2008).

75. Robert Pollin, Heidi Garrett-Peltier, James Heintz, et al., Green Recovery: A Program to Create Good Jobs and Start Building a Low-Carbon Economy (Washington, D.C.: Center for American Progress, September 2008) <www.americanprogress.org/ issues/2008/09/pdf/green_recovery.pdf> (accessed January 1, 2009).

76. KEMA (Jan 13, 2009) The U.S. Smart Grid Revolution KEMA's Perspectives for Job Creation, <www.kema.com> (accessed April 10, 2009).

77. Impact Assessment of Smart Metering Roll Out for Domestic Consumers and for Small Businesses, BERR/DECC <www.berr.gov.uk/files/file45794.pdf> (accessed April 22, 2009).

78. ONS, Annual Business Enquiry, 2008.

79. Here again we use a network multiplier of 0.33 , a conservative estimate based on the previous measurements of the network multiplier for broadband.

80. Plug-in hybrids can be charged at night when electricity costs to the consumer are low and can feed back electricity into the grid periods of peak demand.

81. Atkinson and Castro, Digital Quality of Life, op. cit., October 1, 2008. 



\section{ABOUT THE AUTHORS}

Dr. Jonathan Liebenau is Reader in Technology Management at the London School of Economics and the author of around 100 articles and over a dozen books, the most recent of which is "Banking on Innovation; modernisation of payment systems" with Tanai Khiaonarong (Springer, 2009).

Dr. Robert D. Atkinson is President of the Information Technology and Innovation Foundation, a Washington, DC-based technology policy think tank. He is also author of the The Past and Future of America's Economy: Long Waves of Innovation that Power Cycles of Growth (Edward Elgar, 2005).

Patrik Kärrberg is an engineer and expert on innovation in telecommunications, the software industry, and its business models. He lived in Japan for 5 years, and has held senior management positions in Japan, Scandinavia and continental Europe. Mr. Karrberg is an Associate with LSE Enterprise Ltd. and a Researcher with the Information Systems and Innovation Group (ISIG) in LSE's Department of Management.

Daniel Castro is a Senior Analyst with ITIF. His research interests include technology policy, security, and privacy. Mr. Castro has an MS in information security technology and management from Carnegie Mellon University.

Stephen Ezell is a Senior Analyst with ITIF, with a focus on international information technology competitiveness and national innovation policies. Mr. Ezell comes to ITIF from Peer Insight, an innovation research and consulting firm he co-founded in 2003 to study the practice of innovation in service industries. At Peer Insight, Mr. Ezell co-founded the Global Service Innovation Consortium, published eight research papers on service innovation, and researched national service innovation policies being implemented by governments worldwide.

\section{$* * * * *$}

\section{ABOUT LSE ENTERPRISE LTD.}

A wholly owned subsidiary of LSE, LSE Enterprise enables and facilitates the commercial application of LSE expertise and intellectual resources. Its client list includes major businesses such as BP and Citigroup, UK and other national government agencies and international organisations such as the United Nations and the World Bank.

\section{ABOUT THE INFORMATION TECHNOLOGY AND INNOVATION FOUNDATION}

The Information Technology and Innovation Foundation (ITIF) is a nonprofit, non-partisan public policy think tank committed to articulating and advancing a pro-productivity, pro-innovation and pro-technology public policy agenda internationally, in Washington and in the states. Through its research, policy proposals, and commentary, ITIF is working to advance and support public policies that boost innovation, e-transformation and productivity.

$$
\star * * * *
$$

\section{ACKNOWLEDGMENTS}

LSE Enterprise Ltd. and ITIF extend our thanks to IBM for its generous support to make this research possible.

\section{FOR MORE INFORMATION CONTACT:}

LSE Enterprise Ltd at +44(0)20 79557128 or at enterprise@Ise.ac.uk.

LSE ENTERPRISE LTD I 8th Floor, Tower One, Houghton Street I London I WC2A 2 AE

ITIF at 202-449-1351 or at mail@itif.org, or go online to www.innovationpolicy.org.

ITIF | 1250 I St. N.W. I Suite 200 I Washington, DC 20005 